\title{
THE EFFECTIVENESS OF READING ALOUD STRATEGY IN CONCERNING STUDENTS' READING SKILLS
}

\author{
${ }^{* 1}$ Nurlaily Sofyan, ${ }^{\# 2}$ Jusmin HJ Wahid, ${ }^{* 3}$ Nirwan H Idris \\ ${ }^{* 1}$ English Lecturer, Faculty of Education, Muhammadiyah University of North Maluku, \\ Indonesia \\ \#2 English Lecturer, Faculty of Education, Muhammadiyah University of North Maluku, \\ Indonesia \\ ${ }^{* 3}$ English Student, Faculty of Education, Muhammadiyah University of North Maluku, \\ Indonesia
}

Corresponding Author Email: j.hj.wahid2010@gmail.com

\section{A B S T R A C T S}

Reading Aloud strategy used in the teaching reading skills, which means the teachers and students pronounced the word loudly in front of the class to get the information. The strategy is rewarding for students to understand the reading texts. Then, the researchers used a reading test as an instrument to know the students' competence in reading skills. This research used Quasi-Experimental Design. The result was proved that the score in the experimental class was 61 with a standard deviation was 8.20 and the post-test score was 69.1 with a standard deviation was 8.22 then the score of pre-test in the control class was 56.5 with a standard deviation was 8.53 and post-test was 60.40 with standard deviation was 9. 68. The results achieved from both tests were different. Next, the t-test score both in class was 0,00 . It means that the hypothesis is accepted, it concluded that the implementation of the reading aloud strategy can improve students' reading skills competence.
A R T I C L E I N F O

Article History:

Received: March, 2021

Revised: May, 2021

Published: June, 2021

\section{Keywords:}

Reading Aloud Strategy,

Reading Skills,

How to cite: Sofyan, N., HJ Wahid, J., \& Idris, N. (2021). The Effectiveness of Reading Aloud Strategy in Concerning Students' Reading Skills. Jo-ELT (Journal of English Language Teaching) Fakultas Pendidikan Bahasa \& Seni Prodi Pendidikan Bahasa Inggris IKIP, 8(1), 11-18. doi:https://doi.org/10.33394/joelt.v8i1.3564

\section{INTRODUCTION}

Nur and Djuwairiah (2017) state that reading is a part of language skills that need an interactive through text in comprehending the meaning and got information from written text. To get the meaning of the text the students need the ability like analyzing and interpreting the text so it makes it easy to understand the text itself then the students also should know the aims of the writers' point of views so they can easy to understand the text. Related to this idea the students should dominate the process of readings skills such as pre-reading, reading, understanding, analyzing, and interpreting the text. It becomes the students' problem in mastering all the process of reading skills because the students only focus on the text given by the writer.

Erler \& Finkbeiner (2007; Paris, Lipson, \& Wixson, 1994 in Wang 2016) Reading strategies are self-directed actions where readers flexibly take control with a certain degree of awareness to retrieve, store, regulate, elaborate, and evaluate textual information to achieve reading goals. With reading the students can overcome the problem such as analyzing, 
interpreting and filtering the text. The students systematically arrange the information based on what they read.

Nowadays, a lot of students pretend to the reading skills as the important skill of the language, whereas, they do not possess the ability to understand and interpreting the text. They only read the real text on the paper and judge they read a lot of text without understands, analyzing, and interpreting the text. So it is a big problem for English teachers and lecturers to support their students to have the spirit and motivation in increasing their reading skills. It needs a strategy to be employed by the teacher and lecturer particularly to the students, the strategy used by the teacher and lecturer is the reading aloud strategy.

Sajid and Kassim (2019) Reading has become an increasingly important skill among Saudi students in learning the English language, and reading proficiency are necessary for students to understand written texts for academic achievement. Reading has become an important part of our daily activity. To be more active in getting the information the students should more attention to the key point and main idea of the text.

Reading aloud is the activity of reading by voicing the text, the students read with the right words and intonation to get more information, vocabulary, and improve their pronunciation. The reading aloud strategy helps the students to understand the meaning of the text, getting new vocabulary, improving pronunciation, improving confidence, and make the students enjoy the teaching and learning process.

Bojovic (2010) a reading skill is a cognitive ability that a person is able to use when interacting with the written text. In addition, reading skills involve: identifying word meaning, makes inferences, identifying the writer's point of view, and understanding the factual ideas. So, the students can easy to understand the ideas through reading also can manage, analyze, and interpreting what the authors mean. Then, it also recognizes the types of the text, deducing the meaning, understanding explicitly and non-explicitly information, conceptual meaning, relations within the sentences to sentences through lexical cohesion, and distinguishing the main idea from supporting detail.

The kinds of reading, they are (1) reading for meaning; it is to understand the message which was written in the text. We do not read aloud during we are reading. (2) Reading Aloud; The aims of this reading are not just to understand the text, but also to give information to the listeners, and (3) Reading for comprehension; It means reading with understanding about what are have read. Kustaryo (1988 in Muhaimin, 2019)

Nunan (1999) recommended several purposes of reading: to give the information to students based on their background competence, to give instructions on students to perform how they got the information on the reading text, to understand and give correspondence on reading text, to analyze the information on the reading text, and be able to know what is happening or has happened.

Mckeown and Gentilucci (2007) claim that reading aloud is a method of measuring the cognitive reading process and it is used to measure the competence of reading skills. In accordance with this, reading aloud is a process to build up the students' competence to understand the reading skills. It is the one strategy to make the atmosphere of the classroom is effective and enjoyable in the teaching and reading process. Reading aloud is an effective way because it needs the students' and teacher's feedback to construct the meaning of the text. Then, applying the reading aloud strategy will prompt the students to improve their reading skills.

Zaini et al (2007 in Huda et al 2015) Reading aloud is a learning strategy that emphasizes loud sound with the teacher explaining and overviewing both the beginning and the last of the learning process. This strategy is one of the active learning methods that can help students' concentration, and remand the question and Discussion. Related to Sajid and Kassim (2019) ideas this is an important strategy because it encourages students to read and 
eventually starts to improve their reading comprehension, which in turn enhances their literacy levels.

The aim of the reading aloud strategy is to improve students' competence in understanding, analyzing, and interpreting the text. It makes the students more comfortable in reading activity and giving good motivation to students to elaborate more on their pronunciation competence and self-confidence in mastering reading skills. It makes the good atmosphere of the class and students are enjoyable in the teaching and learning activity. In addition, this strategy can make students get information about the text. Based on the description above, the researchers want to know the effect of the reading aloud strategy on students' reading skills.

\section{RESEARCH METHOD Research Design}

This research used an Experimental Design, the design is a Non-equivalent Control Group Design which is involving two groups of classes. One group was used as the experimental class and another group was used as the controlled class. The researchers used pre-test and post-test designs in both classes.

\section{Population and Sample}

The population of this research was the second-grade students of SMP Negeri 1 Satap Wasile. It is consisting of 40 students both male and female. Then, the researchers conduct this research by applying the reading aloud strategy.

\section{Instruments}

The researchers used a reading test as an instrument. The test was used to know the students' competence in understanding reading text. In this case, the researchers gave the students a reading test using the reading aloud strategy.

\section{Data Analysis}

Wahid (2020) Data analyzing technique used SPSS-16 to continuation process from data processing to observe how to interpret the data, and analyze the data from the output which have in the output phase of the data tabulation. The researchers try to describe the steps in collecting data for the investigation. In this technique of analyzing data, the researchers use triangulation of data analysis: (a) the mean formula; the mean is used to find out the average scores. It is an efficient measurement of control tendency. (b) Standard deviation; the standard deviation is used in order to average variability of the scores around the mean. (c) Categorization; to find out criteria of the students' competence in understanding reading text.

\section{RESEARCH FINDINGS AND DISCUSSION}

\section{Research Findings}

The results of the data analysis; reading skill test which is used by the researcher consists of pre-test and post-test. The pre-test was given to find out the students' competence in reading skills and the post-test was given to find out the improvement of the students' reading skills after the researchers were giving the treatment. 
Table 1

The score of pre-test in the experimental class

\begin{tabular}{|c|c|c|c|c|}
\hline No & Interval & Frequency & Percentage & Category \\
\hline 1. & $90-100$ & 0 & $0 \%$ & Very Good \\
\hline 2. & $76-89$ & 1 & $0.5 \%$ & Good \\
\hline 3. & $61-75$ & 5 & 0.25 & Fair \\
\hline 4. & $51-60$ & 14 & 0.7 & Poor \\
\hline
\end{tabular}

Table 1 shows the students' reading skills after the researchers conduct the research. Then, the researchers classified it into several categorizations. It can be seen that 1 student gets good categorization or (5\%), 5 students get fair categorization or (25\%), and 14 students get poor categorization or $(7 \%)$. So, based on the score and categorization above the students still get the lowest score.

Table 2

The score of the post-test in the experimental class

\begin{tabular}{|c|c|c|c|c|}
\hline No & Interval & Frequency & Percentage & Category \\
\hline 1. & $90-100$ & 0 & $0 \%$ & Very Good \\
\hline 2. & $76-89$ & 5 & $0.25 \%$ & Good \\
\hline 3. & $61-75$ & 7 & 0.35 & Fair \\
\hline 4. & $51-60$ & 8 & 0.4 & Poor \\
\hline
\end{tabular}

It presented in table 2, there were 5 students get good categorization or $(25 \%)$ it showed that the students had increased competence in understanding, analyzing, and interpreting the reading text, 7 students get the fair categorization or $(35 \%)$ it showed the students are rich their critical thinking of the text, and 8 students get poor categorization or $(4 \%)$ it showed that the students persist the same mistake, the students should a lot of practicing at their home to overcome the problem. Based on the result above, the score in the post-test was higher and the students are good competence in reading skills.

Table 3

The score of the pre-test in the control class

\begin{tabular}{|c|c|c|c|c|}
\hline No & Interval & Frequency & Percentage & Category \\
\hline 1. & $90-100$ & 0 & $0 \%$ & Very Good \\
\hline 2. & $76-89$ & 0 & $0 \%$ & Good \\
\hline 3. & $61-75$ & 4 & 0.2 & Fair \\
\hline 4. & $51-60$ & 9 & 0.45 & Poor \\
\hline 5. & 50 & 7 & 0.35 & Very poor \\
\hline
\end{tabular}

Table 3 shows the score in the control class from 20 students. There were 4 students who got a fair score or (2\%), 9 students who got a poor score or (45\%), and 7 students who got less than 50 score or (35\%) Based on the score above the students still got the average score. 
Table 4

The score of the post-test test in the control class

\begin{tabular}{|c|c|c|c|c|}
\hline No & Interval & Frequency & Percentage & Category \\
\hline 1. & $90-100$ & 0 & $0 \%$ & Very Good \\
\hline 2. & $76-89$ & 0 & $0 \%$ & Good \\
\hline 3. & $61-75$ & 4 & 0.2 & Fair \\
\hline 4. & $51-60$ & 9 & 0.45 & Poor \\
\hline 5. & 50 & 7 & 0.35 & Very poor \\
\hline
\end{tabular}

Table 4 shows that the score in the control class from 20 students. There were 4 students who got a fair score or $(2 \%), 9$ students who got a poor score or $(45 \%)$, and 7 students who got less than 50 score or $(35 \%)$. It means that they still got the average score.

The mean score of the experimental class was 61 and a standard deviation was 8.20 (pre-test), the mean score of the control class was 56.05 and a standard deviation was 8.53 (post-test), the mean score of the experimental class was 69.1 and the standard deviation was 8.22. (Post-test), and the mean score of the control class was 60.4 and a standard deviation was 9.68 (post-test). It revealed that the mean score and standard deviation of pre-test and post-test of the experiment and control class were different which was obtained from the students' score above.

Based on the score above, it could be concluded that the student's competence in the experimental class was higher than the students' competence in the control class. While the post-test score in the control class from 20 students as the table above shows, that none of the students $(0 \%)$ got very good score and a good score, fourth students got the fair score or $(2 \%)$ nine students got a poor score or $(45 \%)$, seventh students got very poor or (30\%) it can be concluded that the rate percentage in the post-test was greater than pre-test.

Table 5

The result of the t-test calculation

\begin{tabular}{ccc} 
Variable & t-test value & Level $(\mathbf{p})$ \\
\hline $\mathrm{X} 1-\mathrm{X} 2$ & 0.00 & 0.05
\end{tabular}

The t-test score in table 5 showed that the value of $t$ is $0.00<0.05$. It means that the alternative hypothesis is accepted, with this value it can be concluded that the reading aloud strategy can improve students' reading skills and effective ways used in the teaching and learning process.

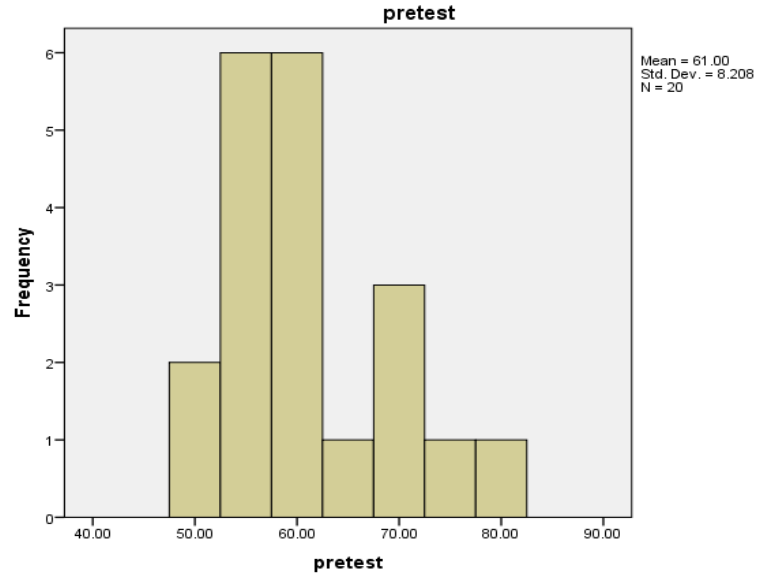

Figure 1. Diagram of the pre-test in the experiment class (Source: SPSS-21) 
Based on figure 1 showed that the students still got the average score in reading competence. It needs that the students should improve their reading skills through the reading aloud strategy.

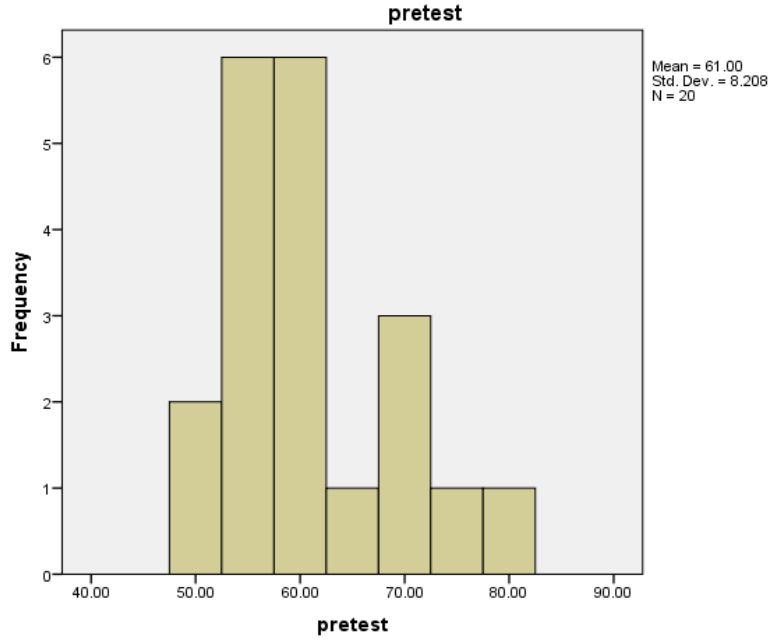

Figure 2. Diagram of the post-test in the experiment class (Source: SPSS-21)

Figure 2 showed that the students got significant improvement after they got material through the teacher, the teachers explain them through the reading aloud strategy to improve their reading skill to understand the reading text.

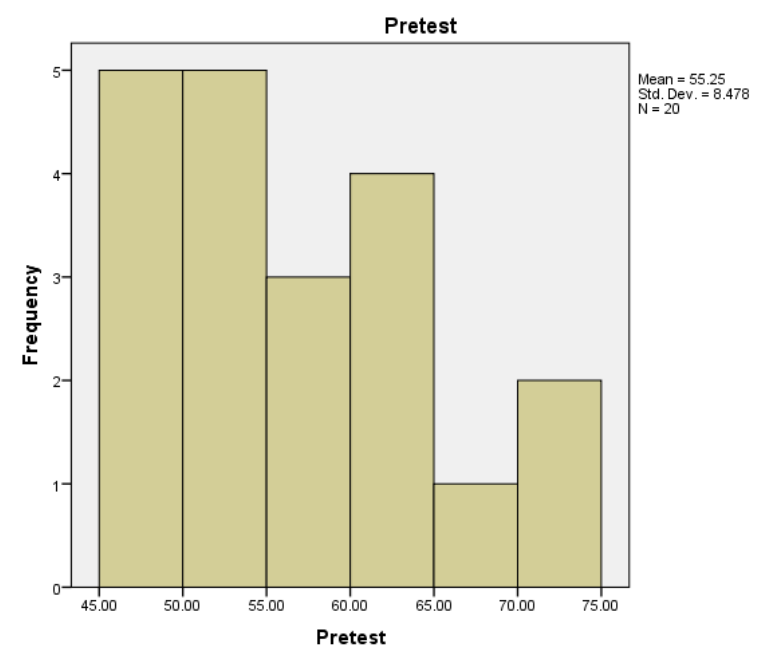

Figure 3. Diagram of the pre-test in the control class (Source: SPSS-21)

Figure 3 showed that the students still got the average score in reading competence. It needs that the students should improve their reading skills through the reading aloud strategy. 


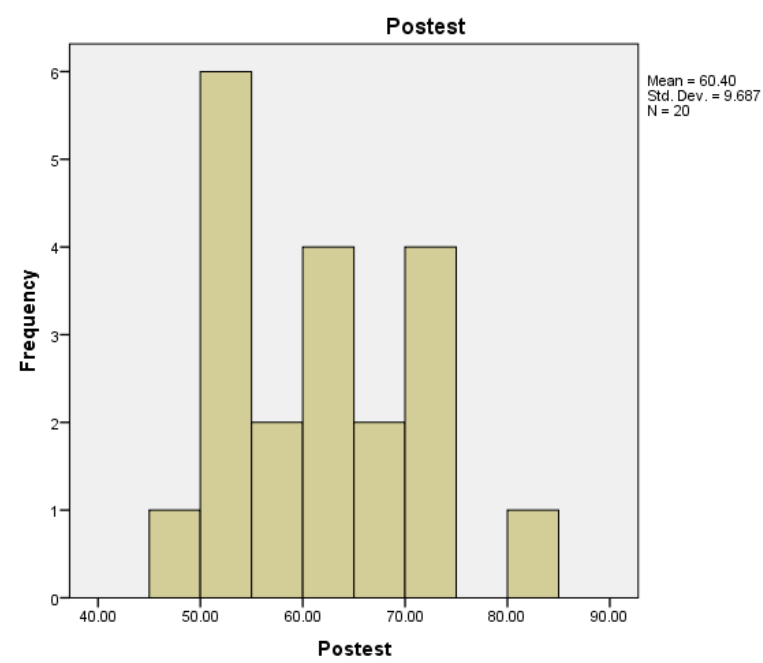

Figure 4. Diagram of the post-test in the control class (Source: SPSS-21)

In figure 4, the students still got the average score in reading competence. It means that the reading aloud strategy should use in teaching reading skills to improve the student's competence in reading skills.

\section{Discussion}

Based on the observation previously, the researchers found a lot of students are hard to understand while analyzing and interpreting the reading text. So, it makes the researchers spend a lot of time conducting this research through teaching. This strategy used by the researchers in the teaching and learning process is the reading aloud strategy. This strategy is believed that can overcome the students' problem in reading skills. In addition, the reading Aloud strategy is one of the most important strategies in teaching reading skills, which means the teachers and students pronounced the word loudly in front of the class and getting the information. This strategy helps the students focus on the content of the text because the words are pronounced loudly and it is saved in students' memories.

Based on the result above, the students are well competent in understanding, analyzing, and interpreting the text through the reading aloud strategy. It is proved by the score of the pre-test in the experimental class was 61 and the standard deviation is 8.02 and the post-test score was 69.1 and the standard deviation is 8.22. Meanwhile, the result of the pre-test in the control class was 56.05 and a standard deviation is 8.53 and the post-test score was 60.4 and a standard deviation is 9.68. Then, the result of the t-test was $0,00<0,05$ It means that reading aloud is an effective and enjoyable strategy used in the teaching and learning class.

This finding was consistent with (Huda et al, 2015) learning process by using reading aloud strategy seems to have been comprehensively successful. It means that through implementing this kind of learning strategy, the students' achievement including activeness, atmosphere, and fluency. In addition, (Sajid and Kassim, 2019) Reading comprehension can be improved by reading aloud strategies. Research has shown that this strategy if used very well by the expert teachers is the only single most important one that can improve not only reading proficiency but also text understanding for improving reading comprehension skills.

\section{CONCLUSION}

The researchers found that there was a significant difference between the experimental and control classes. The value of t-test is $0,00<0,05$. It means that the reading aloud strategy could improve the students' competence in reading skills. Reading aloud strategy had also given positive effect on students. It makes the student more active to pronounce the word 
loudly. Then, the reading aloud strategy improves students' competence in understanding, analyzing, and interpreting the reading text.

\section{ACKNOWLEDGEMENT}

This thesis would not be finished without any help from the others. Therefore, the researchers wish to give appreciation and thanks to all colleagues who have support and giving comments in any part of this article. Criticisms or suggestions from the readers are very much expected to perfect this article. Furthermore, researchers hope this article can help readers to add scientific specialties.

\section{REFERENCES}

Bojovic. M. (2010). Reading Skills and Reading Comprehension in English for Specific Purposes. Serbia: University of Kragujevac, Faculty of Agronomy Cacak.

Erler, L., \& Finkbeiner. C. (2007). A Review of Reading Strategies: Focus on The Impact of First Language. In A. D. Cohen \& E. Macaro (Eds.), Language learner strategies: Thirty years of research and practice (pp. 187-206). Oxford University Press.

HJ Wahid, J., \& A. Thais, I. (2020). Chunking Strategy; in Enhancing Fourth Semester Students' Reading Skill at English Department of Muhammadiyah University. Jo-ELT (Journal of English Language Teaching) Fakultas Pendidikan Bahasa \& Seni Prodi Pendidikan Bahasa Inggris IKIP, 7(1), 18-25. https://doi.org/10.33394/jo-elt.v7i1.2636.

Huda, M., Ali, O., \& Kartanegara, M. (2015). The Effect of Learning Strategy of Reading Aloud on Students' Achievement in The Subject of Islamic Studies at Secondary School in Semarang. International Journal of Education and Research. 3. 577-588.

Kustaryo, S. (1988). Panduan Pengajar Buku Reading Teachniques. Jakarta: Proyek Pengembangan Lembaga Pendidikan Tenaga Kependidikan.

McKeown, R. G., \& Gentilucci, J. M. (2007). Think-Aloud Strategy: Metacognitive Development and Monitoring Comprehension in the Middle School Second-Language Classroom. Journal of Adolescent \& Adult Literacy - J ADOLESC ADULT LITERACY, 51(2). 136-147. https://doi.org/10.1598/JAAL.51.2.5.

Muhaimin, A. (2019). The Use of Reading Aloud Strategy to Improve Students' Fluency and Pronunciation Accuracy in Reading Skills of the Eighth Grade at Mts Nu Aswaja Tengaran in the Academic Year 2017/2018 [Unpublished Master Thesis]. English Education Department: State Institute for Islamic Studies (IAIN) Salatiga.

Nunan. D. (1999). Second Language Teaching and Learning. Boston: Heinle Publishers.

Nur, A. H., \& Ahmad, D. (2017). Improving Students' Reading Skill through Interactive Approach at the First Grade of Sma N 1 Mare, Bone. ETERNAL: (English, Teaching, Learning, and Research Journal), 3(1), 44-56. https://doi.org/10.24252/Eternal.V31.2017.A5.

Paris, S. G., Lipson, M. Y., \& Wixson, K. K. (1994). Becoming a Strategic Reader. In R. B. Ruddell, M. R. Ruddell, \& H. Singer (Eds.), Theoretical Models and Processes of Reading (pp. 788-810). International Reading Association.

Sajid, M. K. M., \& Kassim, H. (2019). The Effects of Reading Aloud Strategies on text Level Difficulties, Reading Proficiency and Reading Comprehension Skill. International Journal of Language Education and Applied Linguistics (IJLEAL), 9(1), 85-97. https://doi.org/10.15282/ijleal.v9.788.

Wang, Y. H. (2016). Reading strategy use and comprehension performance of more successful and less successful readers: A think-aloud study. Educational Sciences: Theory \& Practice, 16(5), 1789-1813. https://doi.org/10.12738/estp.2016.5.0116.

Zaini, H., Bermawy, M., \& Aryani, S. A. (2008). Strategi Pembelajaran Aktif. Yoyakarta Pustaka Insan Madani dan CTSD UIN Sunan Kalijaga. 